\title{
Results in Sizing and Simulation of PV Applications Based on Different Solar Cell Technologies
}

\author{
Alexandru Diaconu ${ }^{1}{ }^{*}$, Laurentiu Fara ${ }^{1,2}$, Paul Sterian ${ }^{1,2}$, Dan Craciunescu1 ${ }^{1}$, Silvian Fara1 \\ ${ }^{1}$ University Politehnica, Bucharest, Romania \\ ${ }^{2}$ Academy of Romanian Scientists, Bucharest, Romania \\ Email: *diaconu_alex@hotmail.com
}

How to cite this paper: Diaconu, A., Fara, L., Sterian, P., Craciunescu, D. and Fara, S. (2017) Results in Sizing and Simulation of PV Applications Based on Different Solar Cell Technologies. Journal of Power and Energy Engineering, 5, 63-74.

http://dx.doi.org/10.4236/jpee.2017.51005

Received: December 13, 2016

Accepted: January 16, 2017

Published: January 19, 2017

Copyright $\odot 2017$ by authors and Scientific Research Publishing Inc. This work is licensed under the Creative Commons Attribution International License (CC BY 4.0). http://creativecommons.org/licenses/by/4.0/

\begin{abstract}
Modeling and simulation of photovoltaic (PV) systems represents an essential task for the integration of PV panels in current power applications. At the present time, there are sizing tools of photovoltaic systems available on the market, taking into account the proposed energy consumption, site localization and system cost. An advanced specialized program (PVSyst) was considered. The sizing and simulations of two PV important applications were developed using PV modules based on three different technologies: monocrystalline and polycrystalline silicon, as well as CIS. Our results showed how different types of solar cell technologies influenced the final power output and performances for a PV LED lighting, as well as for a PV water pumping system, in terms of overall yield, efficiency and system availability.
\end{abstract}

\section{Keywords}

Photovoltaic, Simulations, Monocrystalline, Polycrystalline, Copper Indium Selenide, Solar Cells, Photovoltaic Lighting, Photovoltaic Water Pumping System

\section{Introduction}

Photovoltaic systems have a wide range of applicability and also include public or privately owned solar-powered lighting systems or solar powered water pumps [1]. Solar pumps offer a clean and simple alternative to fuel-burning engines and generators for domestic water, livestock and irrigation [2]. They are most effective during dry and sunny seasons. They require no fuel deliveries, and very little maintenance. Solar-powered lighting is an effective way to implement illumination solutions in terms of technology and consumption [3]. Global pressures 
were made to protect the environment, which has become a priority. In meeting these types of problems, various systems have been developed to replace traditional lighting with energy efficient lighting. The most common method is the LED (Light Emitting Diode) technology.

Various system simulations and dimensioning were developed for specific regions and applications, but using only one type of PV technology. In the paper "Performance analysis of a $190 \mathrm{kWp}$ grid interactive solar photovoltaic power plant in India", V. Sharma and S. S. Chandel have used polycrystalline modules to assess the performance of a power plant installed in India [4].

In the paper called "Simulation and performance analysis of $110 \mathrm{kWp}$ gridconnected photovoltaic system for residential building in India: A comparative analysis of various PV technology", a similar approach is considered for a system to be implemented in a residential building in India. Four types of PV technologies were simulated to determine performance ratios and energy yield [5].

The purpose of the present paper is to identify the best solar cell technology that offers the highest system performances in a specific location. In order to define the most efficient solution that could be implemented in a given location, simulations were developed using monocrystalline, polycrystalline and CIS photovoltaic modules [6].

\section{Real-Life Usage}

Solar-powered lighting is an effective way to implement illumination solutions in terms of technology and consumption. Global pressures were made to protect the environment, which has become a priority. In meeting these types of problems, various systems have been developed to replace traditional lighting with energy efficient lighting. The most common method is the LED technology (Light Emitting Diode).

The design and simulation also provides general information and guidelines on planning and designing of small solar powered water pump system for use in irrigation and livestock feeding operations. One benefit of using solar energy to power water pump systems is that increased water requirements tend to coincide with the seasonal increase of incoming solar energy. When properly designed, these systems can also result in significant long-term cost savings. Aside irrigation and livestock feeding operations, these systems can and are being used for potable water supply in underdeveloped countries. As more and more groundwater sources become unsafe for drinking purposes, potable water often needs to be drawn from depths that require pumping. A Solar-Powered Water Pumping System uses solar energy to power a pump to supply a village with potable water. Solar pumping systems are also commonly being used where it is too far to walk to a well or where the well only provides seasonally usable water.

\section{About PVSyst Simulation Software}

The PVSyst software used in our study is one of the most comprehensive programs used for sizing and simulations of various PV systems. The software 
manages various types of photovoltaic system analysis like stand-alone PV systems, grid connected of hybrid systems. PVSyst uses meteorological data from international databases as well as detailed information about the component technical specifications [7].

\section{Sizing and Simulations for PV LED Lighting System}

We have chosen the PVSyst software application for comparing various solar cell technologies that could power a photovoltaic lighting system. In order to obtain conclusive results, we varied only the solar cell technologies, but the other components of the system remained unchanged. The sizing for this type of system will be as a stand-alone type, meaning that connection to the local energy grid is not required. Most of this type of systems require means for energy storage, therefore our system will use a solar battery. The PV application must be dimensioned to fully charge the batteries when exposed to maximum intensity for the given application. To avoid the possibility of damaging the system because of solar radiation fluctuations or battery overload, the system will be equipped with a charge controller.

One of the main components of the system is the lighting fixture (Figure 1). This is an ELMA 80-12 component provided by Electromagnetica SA, a company that specialized in manufacturing LED system components for lighting fixtures, and provides the following advantages: easy configuration and install, ecologic product, very high energy efficiency, low heat emissions, high reliability coefficient, low maintenance costs. The main technical parameters provided by Electromagnetica SA in the product technical sheet for the lighting fixture are presented in Table 1, as follows [8].

The PV system is intended to provide two days autonomy, in order to compensate for days with high cloudiness. This feature will result in a slightly oversized PV generator and battery. The types of PV technologies used in the simulations are monocrystalline silicon, polycrystalline silicon and CIS solar cells. In order to choose the most suited solar battery for the system, important factors are considered, like daily energy consumption $(27 \mathrm{~W})$, number of days for system autonomy (2 days), battery voltage (12 V) and discharge coefficient (0.4). To obtain the battery capacity, the following equation was used [9]:

$$
\begin{aligned}
\mathrm{C}_{\text {battery }} & =\frac{\text { Daily Energy Use } \times \text { Number of Autonomy Days }}{\text { Battery Voltage } \times \text { Discharge Coefficient }} \\
& =\frac{27 \mathrm{~W} \times 8 \mathrm{~h} \times 2 \text { days }}{12 \mathrm{~V} \times 0.4}=90 \mathrm{Ah}
\end{aligned}
$$
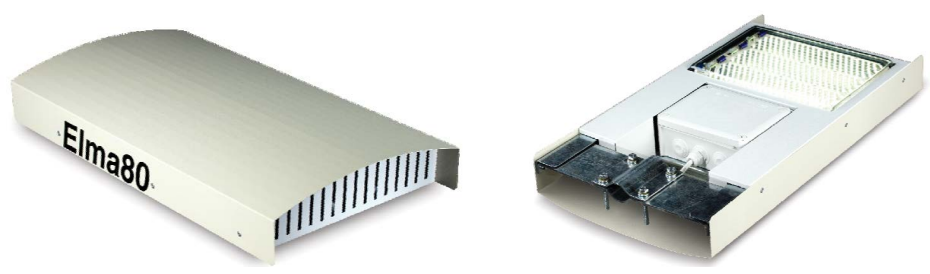

Figure 1. ELBI lighting fixtures. 
Table 1. Main technical characteristics of ELMA LED.

\begin{tabular}{cc}
\hline Technical characteristics & $\begin{array}{c}\text { Code RS81143A } \\
\text { ELMA 80-12 }\end{array}$ \\
Usage & Outdoor perimeter and street lighting \\
Nominal Voltage & $12 \mathrm{Vdc}$ \\
Nominal Power & $27 \mathrm{~W}$ \\
Luminous Flux & $2060 \mathrm{~lm}$ \\
Temperature color & $4800-650 \mathrm{~K}$ \\
Working temperatures & $-40^{\circ} \mathrm{C}+50^{\circ} \mathrm{C}$ \\
Protection & $\mathrm{IP} 65$ \\
Sizes & $582 \times 360 \times 103 \mathrm{~mm}$ \\
Weight & $6 \mathrm{Kg}$ \\
Mounting height & $5-10 \mathrm{~meters}$ \\
\hline
\end{tabular}

Taking this result in consideration, for all the different types of PV technologies used in the simulations, we have considered a Deka battery of 12 V/90 Ah. The solar radiation data for the photovoltaic generators were required from $\mathrm{Me}$ teonorm database for Bucharest site and is presented in Table 2 [10], as monthly daily values $\left[\mathrm{kWh} / \mathrm{m}^{2} /\right.$ day].

Table 3 represents the numerical simulation results for the LED system using monocrystalline silicon modules, while Figure 2 shows the normalized energy and the performance ratio of the system.

The simulation results of the photovoltaic system using monocrystalline silicon shows that for January, November and December months, the system fails to provide $3068 \mathrm{kWh}$ of energy needed. A quantity of $75.68 \mathrm{kWh}$ is lost due to the battery capacity. This problem could be adjusted by lowering the power of the PV modules.

In Table 4, the numerical simulation results for the LED PV system using polycrystalline silicon are presented, while Figure 3 shows the normalized energy and the performance ratio of the PV system.

Results using polycrystalline silicon, as well as the monocrystalline silicon indicate that in January, November and December, the system cannot fulfill the total system energy needs, by a quantity of $2546 \mathrm{kWh}$. Battery losses are also present in the quantity of $80.19 \mathrm{kWh}$. This could also be adjusted by using smaller PV modules but, it is important to take into consideration the solar resources in the months that with low solar radiation.

In Table 5, numerical simulation results for the PV LED system using CIS (Copper, Indium and Selenium) cells are presented, while Figure 4 shows the normalized energy and the performance ratio of the system.

Simulation results for CIS technology shows that a total of $2717 \mathrm{kWh}$ is missing in order for the system to operate at maximum capacity. A total of 80.06 $\mathrm{kWh}$ are lost due to full battery. 
Table 2. Mean daily values for Bucharest location.

\begin{tabular}{ccccccccccccc}
\hline & Jan & Feb & Mar & Apr & May & Jun & Jul & Aug & Sep & Oct & Nov & Dec \\
\hline Hor. Global & 1.40 & 2.49 & 3.55 & 4.75 & 5.86 & 6.53 & 6.58 & 5.75 & 4.17 & 2.74 & 1.53 & 1.12 \\
Hor. diffuse & 0.76 & 1.04 & 1.50 & 2.32 & 2.49 & 2.64 & 2.67 & 2.37 & 1.84 & 1.24 & 0.96 & 0.65 \\
Clrn. index & 0.39 & 0.48 & 0.5 & 0.51 & 0.53 & 0.56 & 0.58 & 0.57 & 0.52 & 0.47 & 0.38 & 0.36 \\
Amb. Temp. & -1 & 1.5 & 6.7 & 11.8 & 17.9 & 21.1 & 23.7 & 23.4 & 17.1 & 11.9 & 6.4 & 0.4 \\
\hline
\end{tabular}

Table 3. Monthly numerical simulation results for PV LED system using monocrystalline silicon modules.

\begin{tabular}{|c|c|c|c|c|c|c|c|c|}
\hline & $\begin{array}{l}\text { GlobHor } \\
\mathrm{kWh} / \mathrm{m}^{2}\end{array}$ & $\begin{array}{l}\text { GlobEff } \\
\mathrm{kWh} / \mathrm{m}^{2}\end{array}$ & $\begin{array}{c}\text { EAvail } \\
\mathrm{kWh}\end{array}$ & $\begin{array}{c}\text { EUnused } \\
\mathrm{kWh}\end{array}$ & $\begin{array}{l}\text { EMiss } \\
\text { kWh }\end{array}$ & $\begin{array}{l}\text { EUser } \\
\text { kWh }\end{array}$ & $\begin{array}{c}\text { E Load } \\
\mathrm{kWh}\end{array}$ & SolFrac \\
\hline Jan & 43.3 & 68.2 & 7.66 & 0.46 & 0.556 & 6.884 & 7.440 & 0.925 \\
\hline $\mathrm{Feb}$ & 69.6 & 103.4 & 11.82 & 3.89 & 0.0 & 6.720 & 6.720 & 1.000 \\
\hline Mar & 109.9 & 137.9 & 15.22 & 7.03 & 0.0 & 7.440 & 7.440 & 1.000 \\
\hline Apr & 142.5 & 153.2 & 16.62 & 8.46 & 0.0 & 7.200 & 7.200 & 1.000 \\
\hline May & 181.7 & 178.6 & 18.64 & 10.38 & 0.0 & 7.440 & 7.440 & 1.000 \\
\hline Jun & 195.8 & 184 & 18.87 & 10.80 & 0.0 & 7.200 & 7.200 & 1.000 \\
\hline Jul & 203.9 & 196.7 & 20 & 11.75 & 0.0 & 7.440 & 7.440 & 1.000 \\
\hline Aug & 178.3 & 187.6 & 19.19 & 10.91 & 0.0 & 7.440 & 7.440 & 1.000 \\
\hline Sep & 125 & 147.2 & 15.46 & 7.51 & 0.0 & 7.200 & 7.200 & 1.000 \\
\hline Oct & 85 & 114.7 & 12.28 & 4.12 & 0.0 & 7.440 & 7.440 & 1.000 \\
\hline Nov & 45.9 & 64.9 & 6.99 & 0.37 & 0.268 & 6.932 & 7.200 & 0.963 \\
\hline Dec & 34.7 & 55.9 & 6.07 & 0.00 & 2.244 & 5.196 & 7.440 & 0.698 \\
\hline Annual & 1415.6 & 1592.5 & 168.81 & 75.68 & 3.068 & 84.532 & 87.600 & 0.965 \\
\hline
\end{tabular}

where: -GlobHor represents Horizontal global irradiation; -GlobEff represents Effective global irradiation corrected for IAM and shadings, where IAM is the Incidence Angle Modifier; -EAvail represents the produced solar energy; -EUnused represents losses due to unused energy; -EMiss represents the missing energy in order for the system to function; -EUser represents the energy supplied to the user; -ELoad represents the energy needed of the user; -SolFrac represents the Solar Fraction, which is calculated as EUser/ELoad [11].

Normalized productions (per installed kWp): Nominal power $130 \mathrm{Wp}$

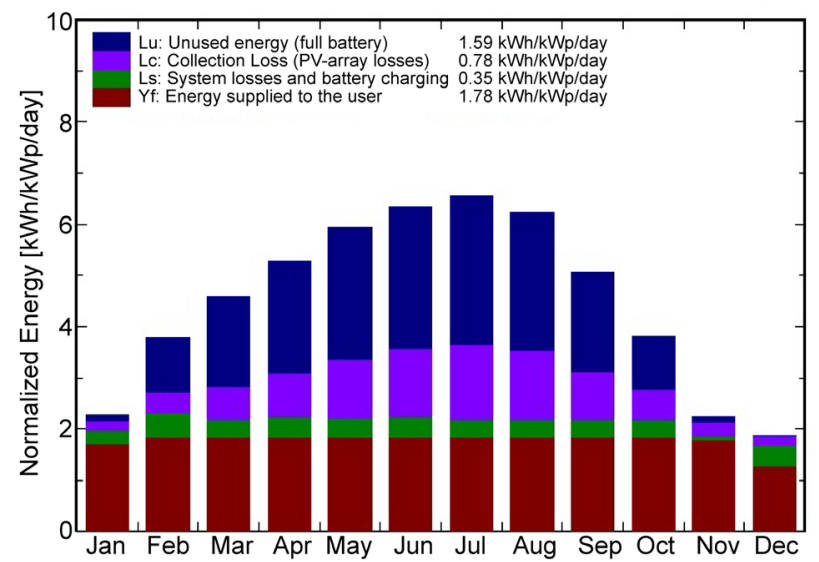

Performance Ratio PR and Solar Fraction SF

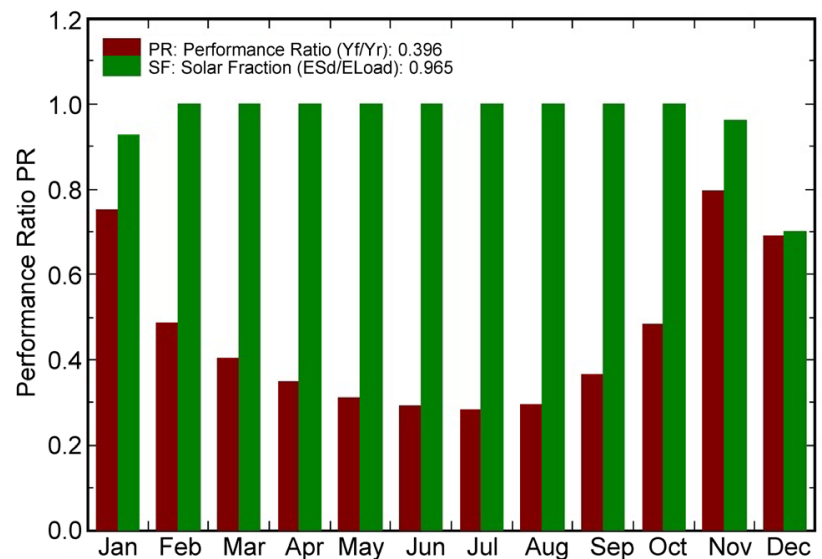

Figure 2. Normalized energy productions, system performance ratio and solar fraction for monocrystalline silicon modules. 
Table 4. Monthly numerical simulation results for PV LED system using polycrystalline silicon modules.

\begin{tabular}{ccccccccc}
\hline & $\begin{array}{c}\text { GlobHor } \\
\mathrm{kWh} / \mathrm{m}^{2}\end{array}$ & $\begin{array}{c}\text { GlobEff } \\
\mathrm{kWh} / \mathrm{m}^{2}\end{array}$ & $\begin{array}{c}\text { EAvail } \\
\mathrm{kWh}\end{array}$ & $\begin{array}{c}\text { EUnused } \\
\mathrm{kWh}\end{array}$ & $\begin{array}{c}\text { EMiss } \\
\mathrm{kWh}\end{array}$ & $\begin{array}{c}\text { EUser } \\
\mathrm{kWh}\end{array}$ & $\begin{array}{c}\text { ELoad } \\
\mathrm{kWh}\end{array}$ & $\begin{array}{c}\text { SolFrac } \\
\text { Jan }\end{array}$ \\
\hline Feb & 63.3 & 68.2 & 7.94 & 0.63 & 0.501 & 6.939 & 7.440 & 0.933 \\
Mar & 109.9 & 103.4 & 12.21 & 4.24 & 0.0 & 6.720 & 6.720 & 1.000 \\
Apr & 142.5 & 153.9 & 15.70 & 7.55 & 0.0 & 7.440 & 7.440 & 1.000 \\
May & 181.7 & 178.6 & 19.17 & 10.92 & 0.0 & 7.440 & 7.440 & 1.000 \\
Jun & 195.8 & 184 & 19.38 & 11.31 & 0.0 & 7.200 & 7.200 & 1.000 \\
Jul & 203.9 & 196.7 & 20.53 & 12.29 & 0.0 & 7.440 & 7.440 & 1.000 \\
Aug & 178.3 & 187.6 & 19.70 & 11.42 & 0.0 & 7.440 & 7.440 & 1.000 \\
Sep & 125 & 147.2 & 15.91 & 7.95 & 0.0 & 7.200 & 7.200 & 1.000 \\
Oct & 85 & 114.7 & 12.67 & 4.50 & 0.0 & 7.440 & 7.440 & 1.000 \\
Nov & 45.9 & 64.9 & 7.23 & 0.42 & 0.118 & 7.082 & 7.200 & 0.984 \\
Dec & 34.7 & 55.9 & 6.30 & 0.00 & 1.927 & 5.513 & 7.440 & 0.741 \\
Annual & 1415.6 & 1592.5 & 173.87 & 80.19 & 2.546 & 85.054 & 87.600 & 0.971 \\
\hline
\end{tabular}

Normalized productions (per installed kWp): Nominal power $130 \mathrm{Wp}$
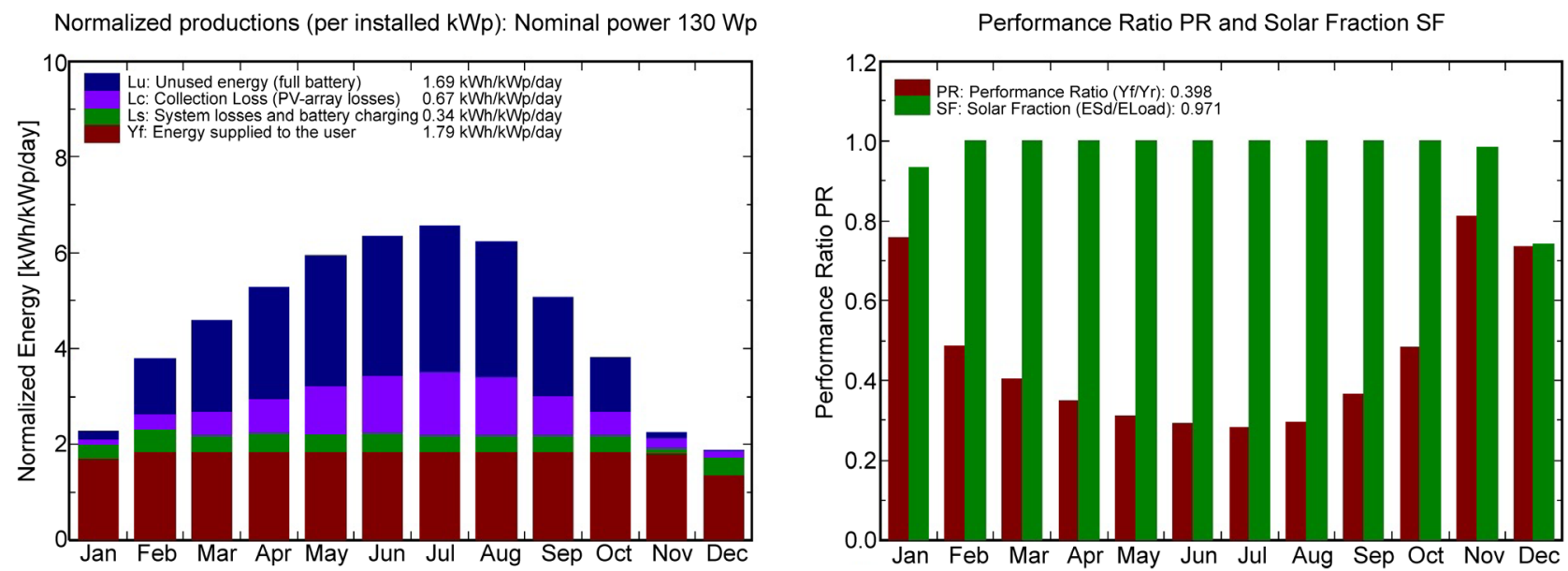

Figure 3. Normalized energy productions, system performance ratio and solar fraction for PV LED system using polycrystalline silicon modules.

Taking into account the obtained results, in this study the polycrystalline silicon offers the best yield. This is highlighted by the annual solar fraction between the energy supplied and the energy needed of the system. However, the overall energy loss caused by the full battery situations is $80.19 \mathrm{kWh}$, which is the highest of the analyzed situations. During the simulations, the modules used are almost identical in means of power and voltage, the main differences are the type of cells used. The simulation program estimates the module losses reported to the power tolerance, namely to a value of half of the inferior tolerance. This value is given by the manufacturers. During simulations, because of different manufacturers and power tolerance values, it could explain the fact that the polycrystalline silicon is more efficient than monocrystallinne silicon. 
Table 5. Monthly numerical simulation results for PV LED system using modules with CIS cells.

\begin{tabular}{ccccccccc}
\hline & $\begin{array}{c}\text { GlobHor } \\
\mathrm{kWh} / \mathrm{m}^{2}\end{array}$ & $\begin{array}{c}\text { GlobEff } \\
\mathrm{kWh} / \mathrm{m}^{2}\end{array}$ & $\begin{array}{c}\text { EAvail } \\
\mathrm{kWh}\end{array}$ & $\begin{array}{c}\text { EUnused } \\
\mathrm{kWh}\end{array}$ & $\begin{array}{c}\text { EMiss } \\
\mathrm{kWh}\end{array}$ & $\begin{array}{c}\text { EUser } \\
\mathrm{kWh}\end{array}$ & $\begin{array}{c}\text { ELoad } \\
\mathrm{kWh}\end{array}$ & $\begin{array}{c}\text { SolFrac } \\
\text { Jan }\end{array}$ \\
43.3 & 68.2 & 7.91 & 0.62 & 0.523 & 6.917 & 7.440 & 0.930 \\
Feb & 69.6 & 103.4 & 12.21 & 4.24 & 0.0 & 6.720 & 6.720 & 1.000 \\
Mar & 109.9 & 137.9 & 15.67 & 7.50 & 0.0 & 7.440 & 7.440 & 1.000 \\
Apr & 142.5 & 153.2 & 17.09 & 8.92 & 0.0 & 7.200 & 7.200 & 1.000 \\
May & 181.7 & 178.6 & 19.15 & 10.90 & 0.0 & 7.440 & 7.440 & 1.000 \\
Jun & 195.8 & 184 & 19.38 & 11.30 & 0.0 & 7.200 & 7.200 & 1.000 \\
Jul & 203.9 & 196.7 & 20.56 & 12.32 & 0.0 & 7.440 & 7.440 & 1.000 \\
Aug & 178.3 & 187.6 & 19.73 & 11.45 & 0.0 & 7.440 & 7.440 & 1.000 \\
Sep & 125 & 147.2 & 15.89 & 7.94 & 0.0 & 7.200 & 7.200 & 1.000 \\
Oct & 85 & 114.7 & 12.62 & 4.47 & 0.0 & 7.440 & 7.440 & 1.000 \\
Nov & 45.9 & 64.9 & 7.17 & 0.41 & 0.301 & 6.899 & 7.200 & 0.958 \\
Dec & 34.7 & 55.9 & 6.25 & 0.0 & 1.892 & 5.548 & 7.440 & 0.746 \\
Annual & 1415.6 & 1592.5 & 173.61 & 80.06 & 2.717 & 84.883 & 87.600 & 0.969 \\
\hline
\end{tabular}

Normalized productions (per installed kWp): Nominal power $130 \mathrm{Wp}$

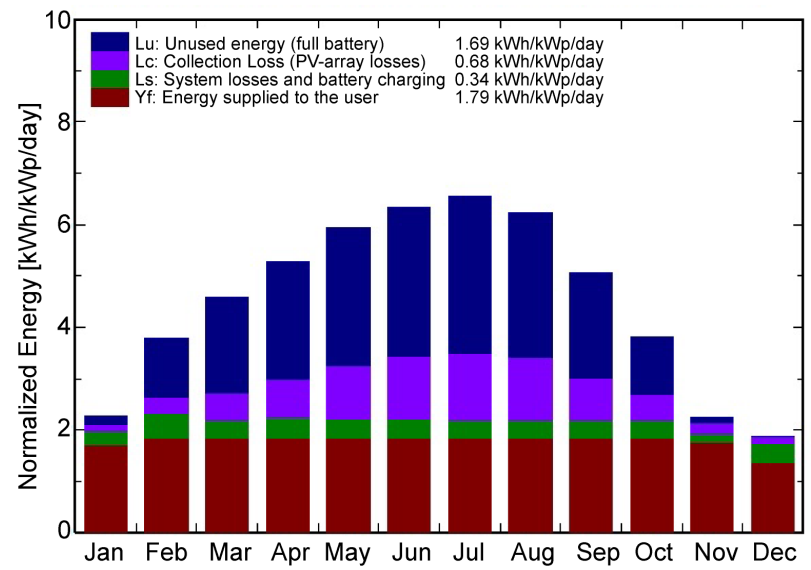

Performance Ratio PR and Solar Fraction SF

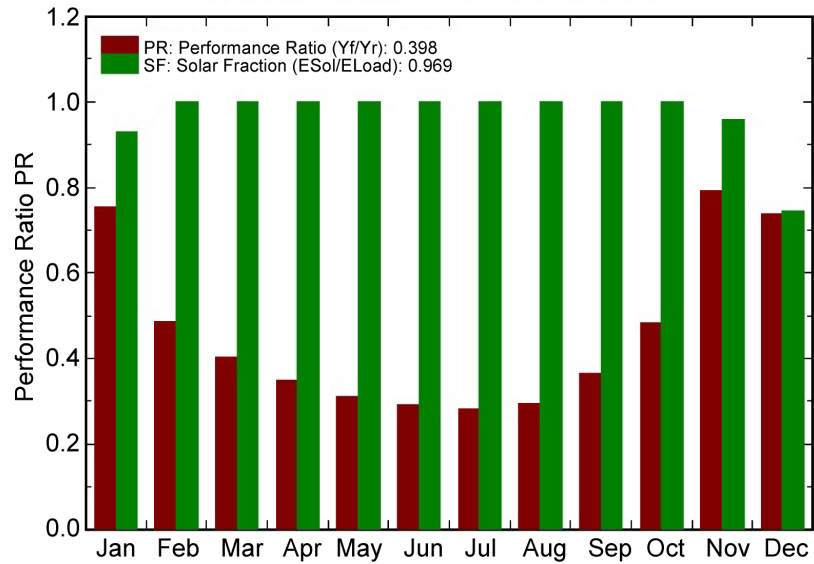

Figure 4. Normalized energy productions, system performance ratio and solar fraction for PV LED system using modules with CIS solar cells.

\section{Sizing and Simulations for PV Water Pumping System}

The PV pumping systems are able to deliver water both for irrigation and local water supply. These pumps are usually using direct current for operation that means that the power could be delivered straight from the PV modules. The pumps that use alternative current are also used but have some disadvantages, for example the system components are more complex and the yield drops when the type of current is changed by inverter.

In order to simulate a PV pumping system properly, we have used specific steps for choosing the right components of the system [12]. These steps are:

1-identification of the water needs, 


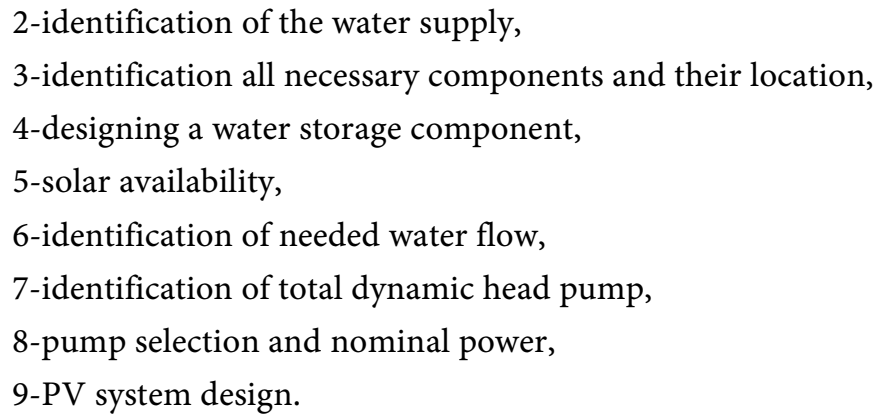

The project simulates the need of water in a farm in Romania. The water need for the project is calculated for 100 cattle. The farm area is contained in 16 hectares of land. We need that the system will be able to supply water in the period of May-September from a water well, when the animals are grazing. A storage tank will also be used, to store the water in order for the system to function in periods with clouds or poor solar availability [13]. A comparison between the different types of PV cells is made and the results are presented in the following tables and figures.

Figure 5 represents the simulation of the PV water pumping system using polycrystalline cell technology.

Table 6 represents the numerical simulation results for polycrystalline cell technology on an average monthly basis.

The results show that from the annual needed water amount of $1460 \mathrm{~m}^{3}$, the system provided an amount of $1331 \mathrm{~m}^{3}$. Energy in the amount of $46 \mathrm{kWh}$ was lost due to the system oversize and annual, the amount of $8.9 \%$ of water was not provided. Months in which the system is unable to provide water are January, February and December. This is due to the low solar radiation availability needed to power the system.

Table 7 represents the numerical simulation results for the PV pumping system using CIS (Copper, Indium and Selenium) cells, while Figure 6 shows the normalized energy and the performance ratio of the system.

Normalized productions (per installed kWp): Nominal power $130 \mathrm{Wp}$

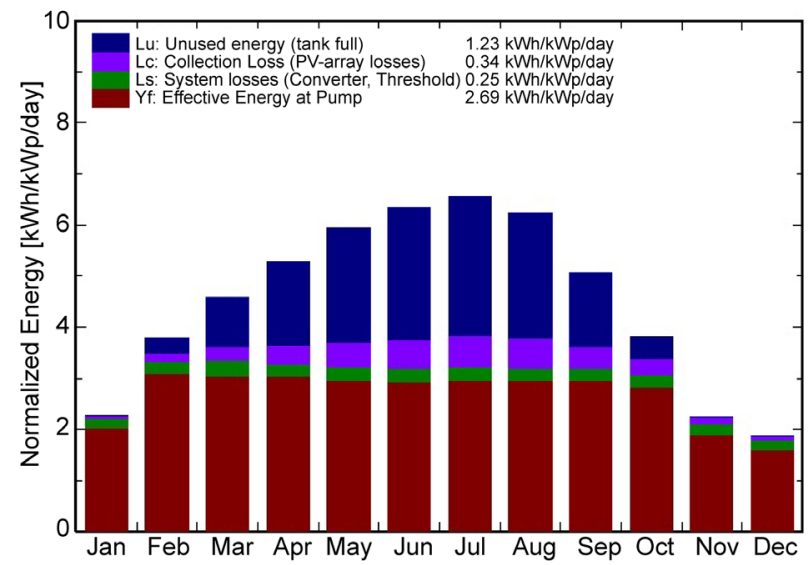

Performance Ratio PR

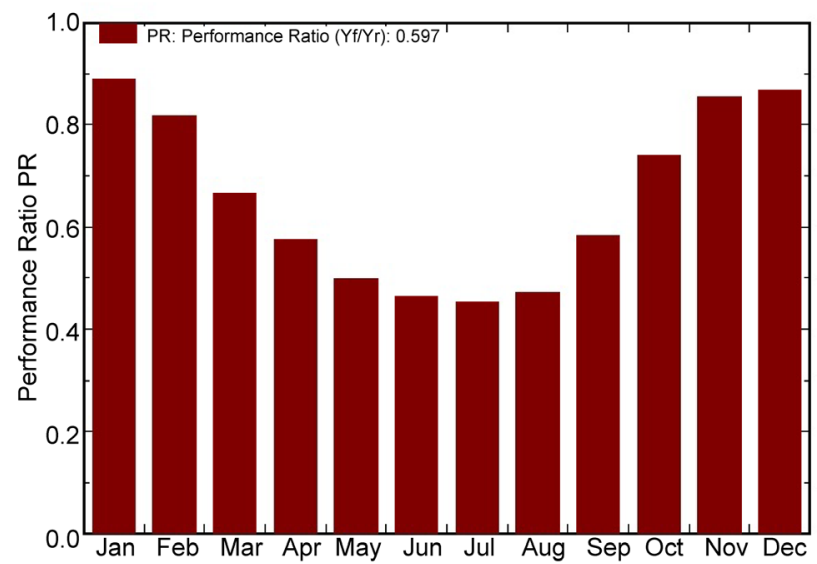

Figure 5. Normalized energy productions, system performance ratio and solar fraction for PV pumping system using polycrystalline silicon modules. 
Table 6. Monthly numerical simulation results for PV pumping system using polycrystalline silicon modules.

\begin{tabular}{|c|c|c|c|c|c|c|c|c|}
\hline & $\begin{array}{l}\text { GlobEff } \\
\mathrm{kWh} / \mathrm{m}^{2}\end{array}$ & $\begin{array}{l}\text { EArrMPP } \\
\mathrm{kWh} / \mathrm{m}^{2}\end{array}$ & $\begin{array}{c}\text { EPmpOp } \\
\text { kWh }\end{array}$ & $\begin{array}{c}\text { ETkFull } \\
\text { kWh }\end{array}$ & $\begin{array}{l}\text { HPump } \\
\text { meterW }\end{array}$ & $\begin{array}{l}\text { WPumped } \\
\mathrm{m}^{3}\end{array}$ & $\begin{array}{c}\text { WUsed } \\
\mathrm{m}^{3}\end{array}$ & $\begin{array}{c}\text { WMiss } \\
\mathrm{m}^{3}\end{array}$ \\
\hline Jan & 68.2 & 8.94 & 8.13 & 0 & 7.936 & 84.8 & 92.8 & 31.19 \\
\hline $\mathrm{Feb}$ & 103.4 & 13.16 & 11.27 & 0.965 & 8.378 & 117.6 & 110.7 & 1.33 \\
\hline Mar & 137.9 & 16.89 & 12.29 & 3.165 & 8.252 & 128.2 & 124 & 0 \\
\hline Apr & 153.2 & 18.35 & 11.83 & 5.195 & 8.222 & 123.5 & 120 & 0 \\
\hline May & 178.6 & 20.57 & 11.92 & 7.119 & 8.109 & 124.4 & 124 & 0 \\
\hline Jun & 184 & 20.73 & 11.44 & 7.749 & 8.084 & 119.4 & 120 & 0 \\
\hline Jul & 196.7 & 21.91 & 11.94 & 8.398 & 8.164 & 124.6 & 124 & 0 \\
\hline Aug & 187.6 & 20.98 & 11.88 & 7.643 & 8.243 & 124 & 124 & 0 \\
\hline Sep & 147.2 & 17.14 & 11.49 & 4.411 & 8.134 & 119.8 & 120 & 0 \\
\hline Oct & 114.7 & 13.83 & 11.36 & 1.410 & 8.107 & 118.6 & 124 & 0 \\
\hline Nov & 64.9 & 8.22 & 7.46 & 0 & 7.815 & 77.8 & 85.3 & 34.71 \\
\hline Dec & 55.9 & 7.26 & 6.52 & 0 & 7.767 & 68 & 66.7 & 57.35 \\
\hline Annual & 1592.5 & 187.98 & 127.54 & 46.055 & 8.111 & 1330.6 & 1335.4 & 124.58 \\
\hline
\end{tabular}

where: -GlobEff represents Effective Global radiation correlated for IAM shadings; -EArrMpp represents Array virtual energy at MPP; -EPmpOp Pump represents the operating energy; -ETkFullis the unused energy (when the water tank is full); -WPumped represents the amount of water pumped; -WUsed represents the water drawn by the user; -WMiss represents the missing water [14].

Table 7. Monthly numerical simulation results of PV pumping system using modules with CIS cells.

\begin{tabular}{|c|c|c|c|c|c|c|c|c|}
\hline & $\begin{array}{l}\text { GlobEff } \\
\mathrm{kWh} / \mathrm{m}^{2}\end{array}$ & $\begin{array}{l}\text { EArrMPP } \\
\mathrm{kWh} / \mathrm{m}^{2}\end{array}$ & $\begin{array}{c}\text { EPmpOp } \\
\text { kWh }\end{array}$ & $\begin{array}{c}\text { ETkFull } \\
\text { kWh }\end{array}$ & $\begin{array}{l}\text { HPump } \\
\text { meterW }\end{array}$ & $\begin{array}{l}\text { WPumped } \\
\mathrm{m}^{3}\end{array}$ & $\begin{array}{c}\text { WUsed } \\
\mathrm{m}^{3}\end{array}$ & $\begin{array}{c}\text { WMiss } \\
\mathrm{m}^{3}\end{array}$ \\
\hline Jan & 68.2 & 8.91 & 7.90 & 0 & 7.922 & 82.4 & 90.4 & 33.56 \\
\hline Feb & 103.4 & 13.18 & 11.19 & 0.409 & 8.327 & 116.7 & 110.7 & 1.33 \\
\hline Mar & 137.9 & 16.89 & 12.33 & 1.757 & 8.155 & 128.7 & 124 & 0 \\
\hline Apr & 153.2 & 18.35 & 11.88 & 2.844 & 8.089 & 123.9 & 120 & 0 \\
\hline May & 178.6 & 20.57 & 11.67 & 3.380 & 7.934 & 121.7 & 124 & 0 \\
\hline Jun & 184 & 20.75 & 11.57 & 2.703 & 7.913 & 120.7 & 120 & 0 \\
\hline Jul & 196.7 & 21.95 & 12.07 & 2.500 & 7.915 & 125.9 & 124 & 0 \\
\hline Aug & 187.6 & 21.02 & 11.88 & 2.301 & 7.934 & 123.9 & 124 & 0 \\
\hline Sep & 147.2 & 17.13 & 11.49 & 1.305 & 7.997 & 119.9 & 120 & 0 \\
\hline Oct & 114.7 & 13.80 & 10.32 & 0.721 & 7.953 & 107.6 & 120 & 3.98 \\
\hline Nov & 64.9 & 8.17 & 6.94 & 0 & 7.767 & 72.4 & 73.1 & 46.91 \\
\hline Dec & 55.9 & 7.21 & 6.25 & 0 & 7.567 & 65.2 & 64 & 59.99 \\
\hline Annual & 1592.5 & 187.93 & 125.48 & 17.920 & 7.967 & 1309.2 & 1314.2 & 145.77 \\
\hline
\end{tabular}


Normalized productions (per installed kWp): Nominal power $130 \mathrm{Wp}$

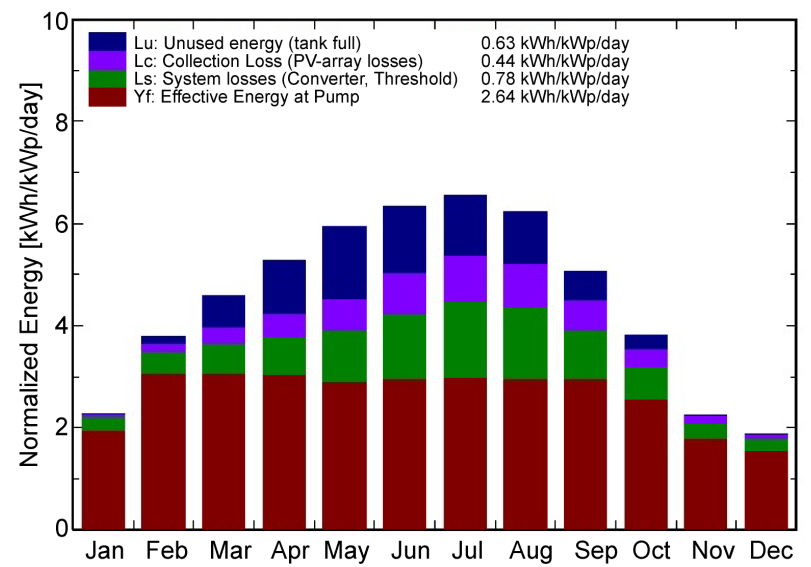

Performance Ratio PR

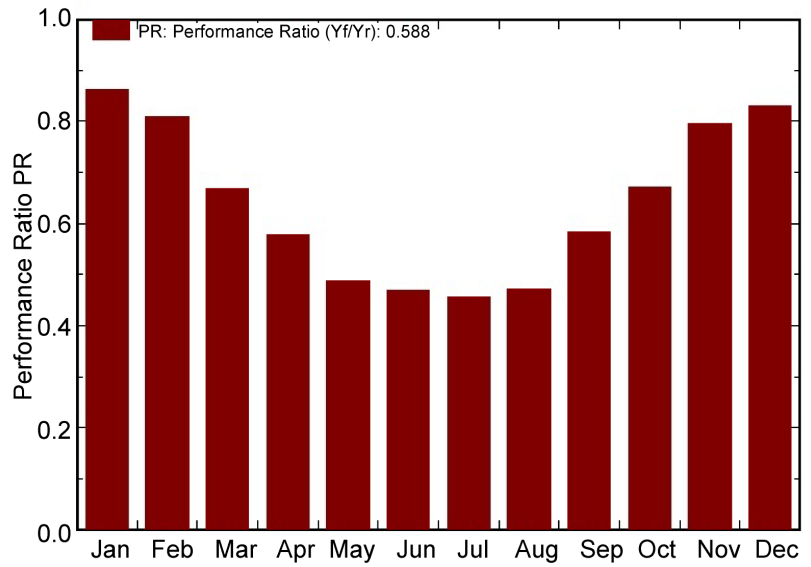

Figure 6. Normalized energy productions, system performance ratio and solar fraction for PV pumping system using modules with CIS solar cells.

The simulation results conclude that from an annual quantity of $1460 \mathrm{~m}^{3}$ of water, the system provided a quantity of $1309 \mathrm{~m}^{3}$. An overall energy of $18 \mathrm{kWh}$ was lost due to oversizing the system. The annual missing water quantity is $10.3 \%$.

Table 8 represents the numerical simulation results for the PV pumping system using modules with monocrystalline cells, while Figure 7 shows the normalized energy and the performance ratio of the system.

The results show that the system delivered $739 \mathrm{~m}^{3}$ of water. There were no energy losses due to oversizing the system and the overall missing water quantity is of $49.4 \%$. The reason this simulation has a very low yield is due to the fact that the voltage of the PV module (16 V) resides below the converter working voltage $(19-38 \mathrm{~V})$. Another converter more suited for this system could be installed to obtain better results, however in the PVSyst database, such converter doesn't exist.

\section{Conclusions}

Sizing and simulations of a photovoltaic system before installation are a very important step. Critical information could result in finding unknown errors in the system or, why not, enhancing the system overall yield.

This paper shows the results of systems using various solar cell technologies but with almost identical BOS components [15]. For the analyzed systems, our simulations show that polycrystalline solar cell technology offers the best results in terms of overall yield. However, we have to take into consideration that these results are dependent by a series of factors like emplacement, solar resources availability, type of application, operating period, etc., and could differ from other PV application projects in various regions.

Further studies could also take into consideration grid-connected photovoltaic systems, however, in order to improve results, data regarding implementation and simulations of additional system components like inverters and regulators 
Table 8. Monthly numerical simulation results for PV pumping system using modules with monocrystalline silicon cells.

\begin{tabular}{ccccccccc}
\hline & $\begin{array}{c}\text { GlobEff } \\
\mathrm{kWh} / \mathrm{m}^{2}\end{array}$ & $\begin{array}{c}\text { EArrMPP } \\
\mathrm{kWh} / \mathrm{m}^{2}\end{array}$ & $\begin{array}{c}\text { EPmpOp } \\
\mathrm{kWh}\end{array}$ & $\begin{array}{c}\text { ETkFull } \\
\mathrm{kWh}\end{array}$ & $\begin{array}{c}\text { HPump } \\
\text { meterW }\end{array}$ & $\begin{array}{c}\text { WPumped } \\
\mathrm{m}^{3}\end{array}$ & $\begin{array}{c}\text { WUsed } \\
\mathrm{m}^{3}\end{array}$ & $\begin{array}{c}\text { WMiss } \\
\mathrm{m}^{3}\end{array}$ \\
\hline Jan & 68.2 & 8.64 & 7 & 0 & 7.934 & 73.1 & 79.1 & 44.9 \\
Feb & 103.4 & 12.79 & 9.99 & 0 & 8.140 & 104.2 & 103 & 9 \\
Mar & 137.9 & 16.46 & 10.29 & 0 & 7.890 & 107.4 & 108.6 & 15.4 \\
Apr & 153.2 & 17.86 & 9.17 & 0 & 7.683 & 95.7 & 93.2 & 26.8 \\
May & 178.6 & 20.03 & 4.89 & 0 & 7.378 & 51.1 & 53.5 & 70.5 \\
Jun & 184 & 20.19 & 3.19 & 0 & 7.308 & 33.3 & 33.3 & 86.7 \\
Jul & 196.7 & 21.33 & 1.99 & 0 & 7.241 & 20.7 & 20.7 & 103.3 \\
Aug & 187.6 & 20.42 & 1.90 & 0 & 7.233 & 19.8 & 19.8 & 104.2 \\
Sep & 147.2 & 16.65 & 5.05 & 0 & 7.426 & 52.7 & 52 & 68 \\
Oct & 114.7 & 13.40 & 6.63 & 0 & 7.599 & 69.1 & 68.6 & 56.2 \\
Nov & 64.9 & 7.91 & 5.43 & 0 & 7.649 & 56.7 & 56.3 & 63.7 \\
Dec & 55.9 & 6.99 & 5.29 & 0 & 7.770 & 55.2 & 54.5 & 69.5 \\
Annual & 1592.5 & 182.66 & 70.82 & 0 & 7.633 & 739 & 742.9 & 717.1 \\
\hline
\end{tabular}

Normalized productions (per installed kWp): Nominal power $130 \mathrm{Wp}$

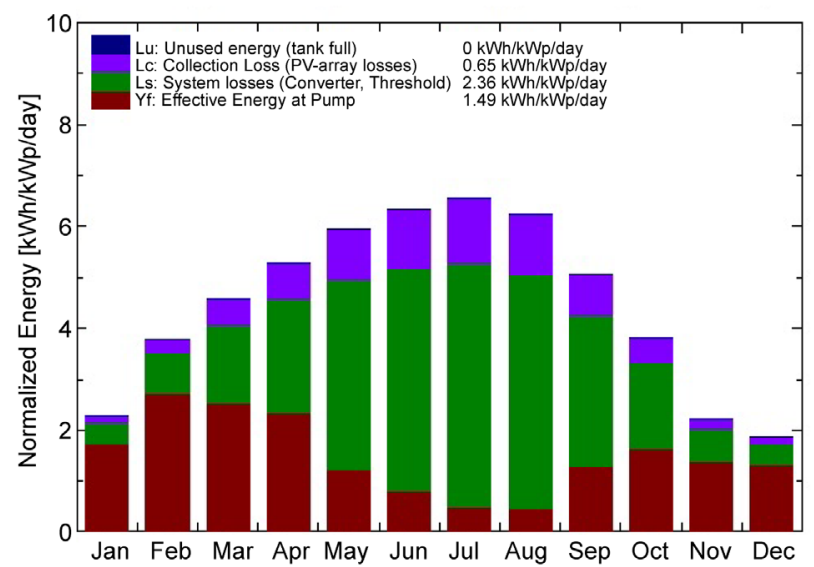

Performance Ratio PR

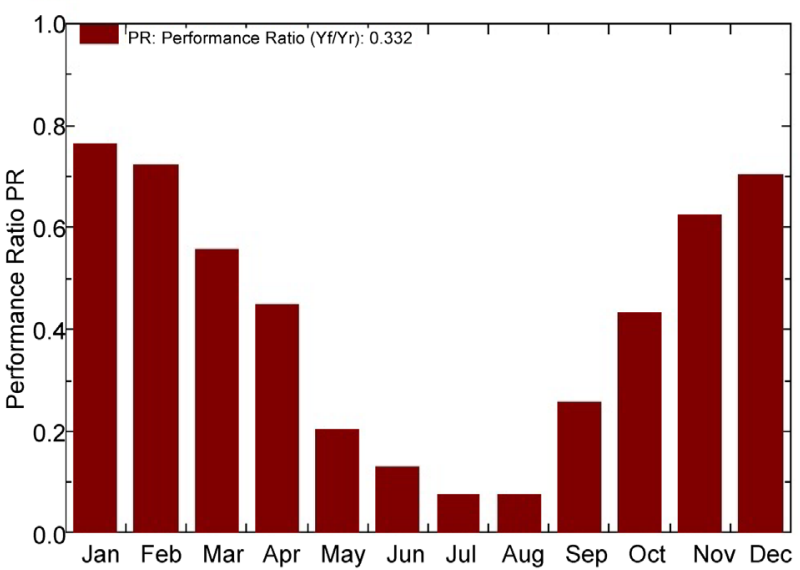

Figure 7. Normalized energy productions, system performance ratio and solar fraction for PV pumping system using monocrystalline silicon cells.

should be considered.

\section{References}

[1] Mohanty, P., Muneer, T. and KolheSolar, M. (2014) Solar Photovoltaic System Applications. In: Mohanty, P., Muneer, T. and Kolhe, M., Eds., Green Energy and Technology, Springer International Publishing, Switzerland, 49-83.

[2] Wikipedia Contributors (2016) Solar-Powered Pump. https://en.wikipedia.org/wiki/Solar-powered_pump

[3] Wikipedia Contributors (2016) Solar Street Light. https://en.wikipedia.org/wiki/Solar_street_light

[4] Sharma, V. and Chandel, S.S. (2013) Performance Analysis of a $190 \mathrm{kWp}$ Grid Interactive Solar Photovoltaic Power Plant in India. Energy, 55, 476-485. 
[5] Shukla, A.K., Sudhakar, K. and Baredar, P. (2016) Simulation and Performance Analysis of $110 \mathrm{kWp}$ Grid-Connected Photovoltaic System for Residential Building in India: A Comparative Analysis of Various PV Technology. Energy Reports, 2, 8288 .

[6] Mohammad, B.A., Mahmoud, M.A.V. and Mohsen, M. (2015) Types of Solar Cells and Application. American Journal of Optics and Photonics, 3, 94-113. https://doi.org/10.11648/j.ajop.20150305.17

[7] PVsyst SA (2016). http://www.pvsyst.com/en/about-us

[8] Electromagnetica SA (2016).

http://www.elma-led.ro/lampa-stradala-perimetrala-elma-80-12-cu-led\#tab-product -view2

[9] Li, J., Wei, W. and Xiang, J. (2012) A Simple Sizing Algorithm for Stand-Alone PV/Wind/Battery Hybrid Microgrids. Energies, 5, 5307-5323.

[10] Meteotest (2016).

http://www.meteonorm.com/en/downloads/horizonhttp://files.pvsyst.com/help/sim ulation_variables_standalone.htm

[11] United States Department of Agriculture (2010) Design of Small Photovoltaic (PV) Solar-Powered Water Pump Systems. Technical Note No. 28, Portland, Oregon. https://www.nrcs.usda.gov/Internet/FSE_DOCUMENTS/nrcs142p2_046471.pdf

[12] Diaconu, A., Moraru, A. and Fara, L. (2013) PV Pumping Systems. Case Study: Sheep Farm in South Romania. Proceedings of the International Conference on Energy Efficiency and Agricultural Engineering, Ruse, Bulgaria, 17-18 May 2013, 606-616.

[13] PVsyst SA (2016). http://files.pvsyst.com/help/index.html?simulation_variables_standalone.htm

[14] Fara, L., Bartok, B., Moraru, A., Oprea, C., Sterian, P., Diaconu, A. and Fara, S. (2013) New Results in Forecasting of Photovoltaic Systems Output Based on Solar Radiation Forecasting. Journal of Renewable and Sustainable Energy, 5, Article Number: 041821. https://doi.org/10.1063/1.4819301

[15] Fara, L. and Yamaguchi, M. (2013) Advanced Solar Cell Materials, Technology. IGI Global, Hershey.

Submit or recommend next manuscript to SCIRP and we will provide best service for you:

Accepting pre-submission inquiries through Email, Facebook, LinkedIn, Twitter, etc. A wide selection of journals (inclusive of 9 subjects, more than 200 journals)

Providing 24-hour high-quality service

User-friendly online submission system

Fair and swift peer-review system

Efficient typesetting and proofreading procedure

Display of the result of downloads and visits, as well as the number of cited articles

Maximum dissemination of your research work

Submit your manuscript at: http://papersubmission.scirp.org/

Or contact jpee@scirp.org 